\title{
Antecedents of use of e-health services in Central Eastern Europe: a qualitative comparative analysis
}

\author{
Marek Ćwiklicki ${ }^{1 *} \mathbb{D}$, Francesco Schiavone ${ }^{2,3}$, Jacek Klich ${ }^{1}$ and Kamila Pilch ${ }^{1}$
}

\begin{abstract}
Background: The objective of this paper is to identify the key conditions that positively affect the use of e-health services in Central Eastern Europe (CEE) countries. CEE countries after the political and economic transformation in 1989/90 implemented slightly different national health care models. The research question of the study is: how do the various institutional conditions at the national level affect the use of e-health services in CEE countries?

Methods: The e-health description was derived from papers indexed in Web of Science and Scopus. The data for computation were collected from the 2015 global survey by the WHO Global Observatory for eHealth. We used a narrative literature review in order to identify key terms associated to e-health and conditions for the implementation of e-health services. The search terms were "e-health" and "**" where * was particular thematic section of e-health according to WHO GOeH. The inclusion criterion was relevance of the paper to e-health and searched phase. Eligibility criteria for countries for being described as CEE countries: Estonia, Lithuania, Latvia, Poland, Hungary, Romania, Bulgaria, Czech Republic, Slovenia, and Croatia (we omitted Slovakia from the analysis because this country was not covered by the WHO Survey). We applied qualitative comparative analysis (QCA) to analyse the necessary order of conditions. The dependent variable of the study is the national rate of use of e-health services.
\end{abstract}

Results: QCA shows that legal medical jurisdiction, teleprogramme and electronic health records supplemented by adequate training constitute critical conditions to achieve success in e-health implementation.

Conclusions: We conclude that the more formalised a framework for e-health service delivery is, the more likely it will be used. Therefore formalisation fosters the diffusion, dissemination and implementation of e-health solutions in this area. Formalisation must be accompanied by tailored training for health care professionals and patients. Our analyses are related only to the paths of e-health implementation in CEE countries thus consequently the findings and conclusions cannot be directly applied to other countries. The limitations of this study are related the absence of a broader context of e-health development, including the development of ICT infrastructure and ICT literacy.

Keywords: E-health, Services, Policy, Central Eastern Europe, QCA

\section{Background}

Digital transformation is one of the main current challenges for companies and institutions in every business

\footnotetext{
* Correspondence: marek.cwiklicki@uek.krakow.pl

'Department of Management of Public Organisations, Cracow University of Economics, ul. Rakowicka 27, 31-510 Cracow, Poland

Full list of author information is available at the end of the article
}

sector $[1,2]$. For a long time, healthcare players have been trying to digitalise their processes, practices and services [3, 4]. Health IT (HIT) offers crucial benefits to companies and institutions in terms of both quality of care (e.g., patient satisfaction and safety) and efficiency/ financial performance (e.g., costs and value added) [3].

(c) The Author(s). 2020 Open Access This article is licensed under a Creative Commons Attribution 4.0 International License, which permits use, sharing, adaptation, distribution and reproduction in any medium or format, as long as you give appropriate credit to the original author(s) and the source, provide a link to the Creative Commons licence, and indicate if changes were made. The images or other third party material in this article are included in the article's Creative Commons licence, unless indicated otherwise in a credit line to the material. If material is not included in the article's Creative Commons licence and your intended use is not permitted by statutory regulation or exceeds the permitted use, you will need to obtain permission directly from the copyright holder. To view a copy of this licence, visit http://creativecommons.org/licenses/by/4.0/ The Creative Commons Public Domain Dedication waiver (http://creativecommons.org/publicdomain/zero/1.0/) applies to the data made available in this article, unless otherwise stated in a credit line to the data. 
To date, one of the main paths crossed by healthcare organisations in implementing digital transformation is the so-called e-health [5]. Within ICT for health, the e-health concept began to appear in the literature in 1999 as an evolution of the telehealth domain [6]. Scholars have greatly explored this topic. E-health refers to all of the "health services and information delivered or enhanced through the Internet and related technologies" [7]. Consequently, ICT is seen as the only channel through which various e-health programmes and initiatives can be provided thus can be seen as a main determinant of e-health. The components of e-health are electronic health records (EHRs), health information, clinical decision support systems, and physician order entry [6]. Since e-health is considered here broadly, as an umbrella term, it covers also subsets like telehealth, telemedicine, and $\mathrm{m}$-health. E-health solutions require the involvement and integration of more knowledge and scientific domains, such as medical informatics, public health, and business [7]. However as Scott and Mars notes: "We have still not agreed upon a universal, standard definition of eHealth, and related terms" [8].

E-health services can be differentiated in terms of technologies, functions, and fields of application [6]. The main e-health services offered to patients can be classified into five categories [9]: 1) Education services, by which institutions can use digital technologies to improve consumers' access to health-related information; 2) E-behaviour change services, by which online support groups and collaborative communities can promote novel and healthier lifestyles among patients; 3) Selfmonitoring and disease management, by which a chronic patient can track via a smartphone his/her own health status without professional support; 4) E-treatment adherence services, by which health professionals can send patients more reminders, at different moments and to different devices to increase their treatment adherence, using telemedicine; and 5) E-surveillance services, by which doctors can implement via EHR systematic and ongoing health assessment (data collection, analysis, interpretation, and dissemination of findings) of the conditions of chronic patients using electronic medical records. As indicated earlier, we consider telemedicine just mentioned above - as an important, growing in value and numbers, subset of e-health. The widespread use of smartphones in people's daily lives has also boosted the rise of mobile health (or m-health) which is treated as another subset of e-health. This is a fastgrowing new market and technological niche born in 2003 just after e-health began [6]. The WHO Global Observatory for eHealth (WHO GOE) defines mobile health as a "medical and public health practice supported by mobile devices, such as mobile phones, patient monitoring devices, personal digital assistants (PDAs), and other wireless devices" [10]. A recent example of the successful use of m-health apps was the collection and use of patient-generated data for supporting diabetes self-management [11]. Recent study finds that "mobile health applications has a positive impact on healthrelated behaviors and clinical health outcomes" [12].

Despite these evident benefits, the introduction of digital services in healthcare can also generate problems, risks and drawbacks. For instance, e-health services can lead to a digital divide among the various segments of the population since some people with low socioeconomic status are less likely to know about and use these services [13]. Privacy and the use of patient data by institutions and companies are other critical issues for all the various domains of e-health [14].

A group of experts in digital health and staff members of the WHO [15] identified 8 antecedents of e-health adoption (Fig. 1), which are reviewed in detail in the next section.

The presence of elements in each of these 8 areas can be associated with successful e-health diffusion and implementation. We use the above framework to bring up particular issues and to critically examine them in light of the narrative literature review.

CEE countries form an important sub-continent for health and industrial policies. The experiences of CEE countries have greatly contributed to transitology (the process of democratisation) $[16,17]$. Despite the common heritage of Semashko's healthcare model (named after the first Minister of Health in the USSR and also called the budget model), which is) highly centralised and based on public financing and service delivery [17-19], after the 1989/90 political and economic transformation, CEE countries implemented slightly different national healthcare models. The latest developments of healthcare systems in these countries remain relatively poorly researched. This article aims at filling this gap at least partially. The objective of this paper is to identify the key conditions that positively affect the implementation of ehealth services within this European sub-continent. Thus, the research question of the present paper is the following: what conditions are necessary and sufficient for achieving an effective use of e-health services in CEE countries?

\section{Methods}

We performed a narrative review because its main purpose was to identify and map the available evidence [20]. We searched for e-health policy components in Web of Science, Scopus and Google Scholar. The review was performed in September 2018. Our search strategy used including the search terms inputted into the databases searched by adding the following explanation: The search string was ["e-health" and "*:"\} where " was particular thematic section of e-health according to WHO GOeH, e.g., e-health and m-health and so on. The searched areas in databases were: the paper's title, abstract, and keywords, 


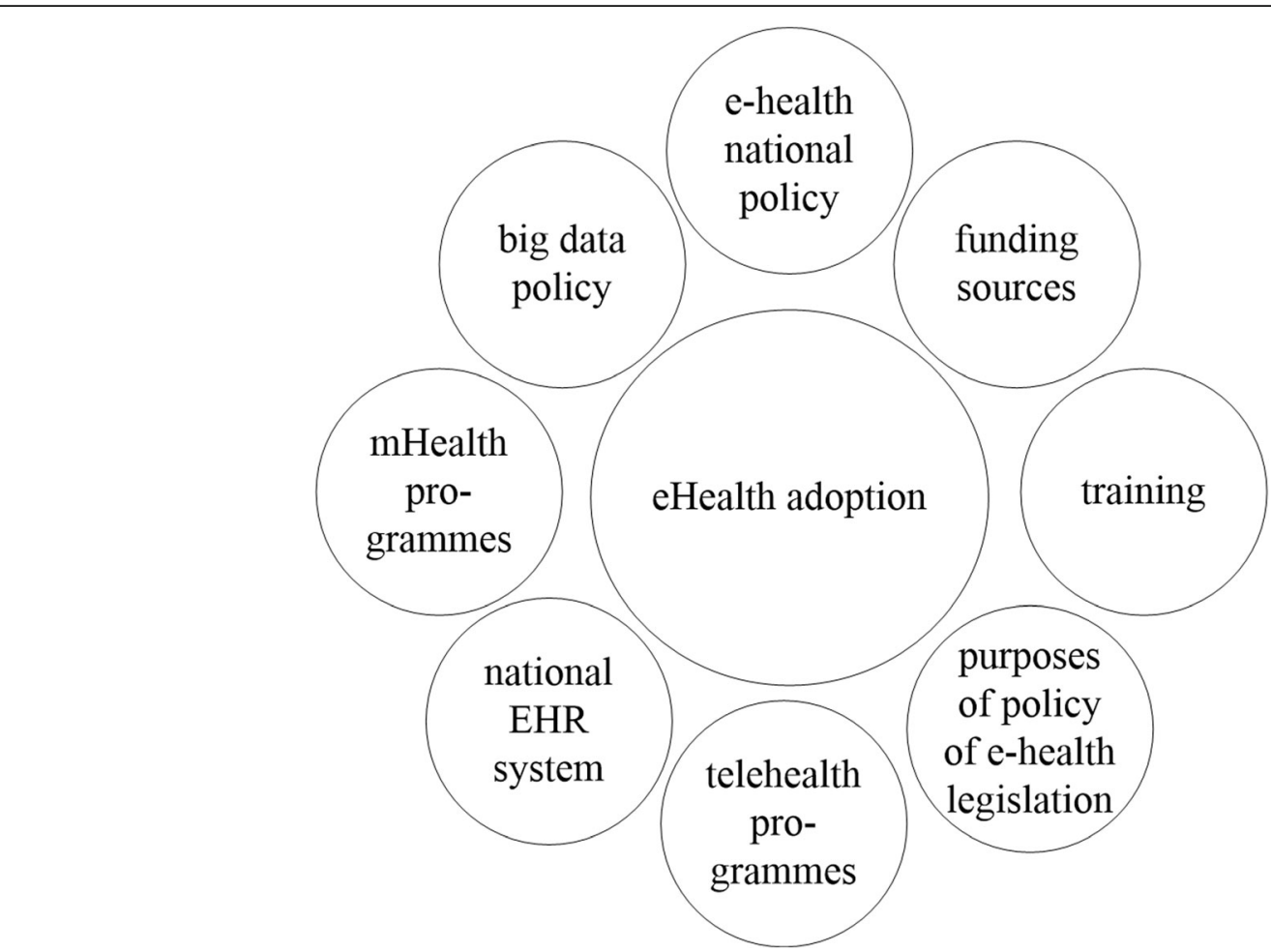

Fig. 1 The thematic sections of e-health. Own elaboration based on [15]

as well as date (as we wanted to refer to recent literature). The inclusion criteria were: relevance of the paper to ehealth and searched phase (fitting into discussed thematic section and refer to CEE), publication date (novelty), source type (reviewed papers). We selected all the papers satisfying all these criteria.

We notice that the WHO GOE covers the most important e-health dimensions with strong reference to policy and strategy. However, the national framework is also a crucial element for spreading the use of e-health.

The implementation of strategies referring to new areas of public service provision requires the adoption of appropriate methodological rigour that fits in the third generation of research on public policy introduction [21]. The qualitative comparative analysis (QCA) method, developed by Ragin, uses Boolean algebra to analyse real patterns and logical formulae. It allows for the determination of logical conclusions from the dataset. In this method, cases are presented as a set of factors and conditions influencing a given effect. QCA is focused on both the case and the variables [22].

Analyses carried out with the use of QCA rely on the identification and calculation of all combinations of the variables occurring in the dataset. A condition is considered necessary if it must be present to achieve a given result and sufficient if it creates the result itself [23]. As Ragin wrote, no single causal condition may be either necessary or sufficient for the outcome in question; instead, only combinations of conditions may be found to be sufficient [22]. QCA minimises the configuration and strictly applies the Mill method, according to which if two configurations differ with respect to only one condition but have the same result, this condition is irrelevant and can be eliminated [22].

Our goals were to identify the key conditions to achieve success in e-health implementation at the national level. At the same time, we wanted to identify which ones are necessary and which are sufficient. Therefore, we first identified (based on the narrative literature review) the outcomes and the conditions to be assessed. The proposed approach and method have been successfully used in other health care studies in which the goal was to identify necessary and sufficient factors (e.g., [24-26]). The QCA method suggests theoretically plausible conditions that with further development could help meet the e-health implementation challenges.

CEE countries are often bypassed in comparative studies into e-health partly because they are behind the developed democracies with respect to ICT $[27,28]$; thus, a concise picture of the most recent developments in the analysed countries seems to be appropriate. Therefore, we present a general description of these countries and the e-health solutions available in each. We present the following countries: Slovakia, Estonia, Lithuania, Czech Republic, Bulgaria, Hungary, and Poland. Next, we discuss all CEE countries in contrast to all EU member states based on composite indicators. 
The overall picture of e-health solutions in operation in the analysed countries is far from complete due to the lack of information, on the one hand, and the dynamics of the process itself, on the other. Below, we present a brief description of the e-health solutions in those CEE countries based on the official reports, announcements, etc. available on national ministry and medical business websites.

As research material, we used data from the third global survey on e-health conducted by the WHO GOE. We focused on the data for 10 Central Eastern European countries (Estonia, Lithuania, Latvia, Poland, Hungary, Romania, Bulgaria, Czech Republic, Slovenia, and Croatia). Because Slovakia was not covered by the WHO survey, we omitted this state from analysis. fsQCA 3.0 software was used to carry out the analysis [29].

The overall research procedure consists of three steps.

1) Measuring outcomes: First, we established the measure for the outcomes. We associated the outcome with the successful delivery of e-health services, which we understand as a high percentage of e-health service use by patients. We used as the measure for outcomes the percentage of use of two e-health services included in the European Life Quality Survey in 2016: prescriptions ordered online or by telephone and medical consultations held online or by telephone [30]. We assumed that if the percentage of prescriptions ordered online or by telephone is greater than or equal to 20 and the percentage of medical consultations held online or by telephone is greater than or equal to 15 , this indicates successful implementation of e-health policies.

2) Identifying and assessing conditions: The next step is to identify relevant causal conditions derived from the WHO Global Observatory for eHealth survey $[31,32]$. Based on the narrative literature review in one of the previous sections, we identified the conditions contributing to the use of e-health services in the CEE countries. To avoid redundancy in the data, we chose the conditions with reference to policy and strategy. We decide to exclude certain conditions from our analysis. As our scope of interest concerns the CEE countries, which are monocultural and mainly mono-ethnic, we did not consider the issue of multilingualism in e-health. Because the use of e-learning in health sciences is covered in the broader concept of capacity building, we do not include it in further examination. According to literature, it is relevant at the individual level, as in doctor-patient interaction. Therefore, it is more relevant for patients and health organisations than for national regulation or policy. The next condition is big data. Although it is an important issue, as suggested in the literature, it is loosely connected to patients' direct use and is more appropriate for e-health governance at the national level. Moreover, the collected data cover this issue to a lesser degree. In the survey, particular e-health programmes were assessed with respect to different system levels (local, intermediate (regional), national, international) and programme types (informal, pilot, established). We chose pilot or established programmes at the national level.

3) Finally, we identified the combination of conditions for the use of e-health. The QCA method enables the study of the most significant similarities and differences among the analysed cases and indicates one or more combinations of conditions that may be equally effective. Using the numerical values for the outcomes and conditions for each of the 10 cases, a truth table was produced. This table displays all of the possible combinations of conditions leading to the outcome.

\section{Results}

In our analysis, there are eight the building blocks of ehealth adoption. The first block is the e-health foundations, which are (a) national policies/strategies, (b) funding sources for e-health, (c) multilingualism in e-health, and (d) e-health capacity building.

\section{National e-health policies}

National policies are important drivers for e-health solutions. At the operational level, the analysis of implementation factors of e-health service adoption has been described in recent works [33]. The analysis of e-health systems showed that the most important issue was their workability, with less emphasis on efficiency [34]. Workability can be assured by a proper legal framework, among other aspects. However, e-health legislation is considered a new issue. Mars and Scott assess legislation in some developed countries as ad hoc patchwork [35]. The authors observe that "information on country-level e-health policies and strategies is not readily available" [35]. An inadequate or fragmented legal framework was mentioned in the e-health Action Plan 2012-2020 among the barriers to the deployment of e-health. Mars and Scott state that e-health policy is fragmented and encompasses different, even separate, yet related strategies, programmes, and national action plans.

In response to social and economic changes, the WHO formulated the guidelines for implementing national e-health strategies [27], and the European Union accepted a respective action plan for the period 2012-2020 [36]. E-health strategies are diffusing. The WHO GOE's report [15] shows that $58 \%$ of surveyed countries have an e-health strategy and that $66 \%$ of them have a national health information system 
policy or strategy. Furthermore, particular EU countries have started to introduce national e-health strategies, which we discuss in the next paper's section with reference to CEE countries. We can conclude that the more a framework for ehealth service delivery is formalised, the more likely it is used. Therefore, we assume that formalisation fosters the diffusion, dissemination and implementation of e-health solutions in this area. We look at the broader context in the model of innovation diffusion in health service organisations [37].

To be more accurate, we refer to external policies and incentives [38] at the national level. We claim that the success of the implementation of e-health services depends on the degree of intensification of established programmes, legal frameworks, state-run policies, etc., which can be named the formalisation of business rules for service delivery or the introduced strategies, regulations and programmes. "National projects" are understood as initiatives undertaken by the Ministry of Health (or/and other central bodies) and implemented nationwide. Of course, there could be other interesting ventures/projects initiated on a small, local scale. However, to obtain a full, concise and heterogeneous picture, we decided to examine "national projects".

\section{Funding sources for e-health}

Reports of financing e-health show that the integration of funding sources is the most significant obstacle [39]. It is suggested that the best way is that of mixed arrangements [39]. This is also observed in a recent study on financial resources and the development and implementation of e-health infrastructure and applications [40]. An analysis of e-health policies shows that publicprivate partnerships are encouraged [41]. Moreover, healthcare organisations should invest in e-health. Nevertheless, the healthcare systems in CEE were developed according to Semashko's model. According to the model, healthcare was financed via state budgets, with citizens having free access to health services $[18,19]$.

\section{Multilingualism in e-health}

According to the WHO GOE, "a national multilingualism policy or strategy promotes linguistic diversity and cultural identity and reflects a government's commitment to inclusion of linguistic minorities in the country" [15]. This issue in scholarship is not undertaken as a key area of introducing e-health. The research refers to multicultural countries, especially those receiving large immigrant populations with limited national language proficiency $[42,43]$.

\section{E-health capacity building}

The fourth topic influencing the adoption of e-health is generally described as capacity building. By this expression, pre- and in-service training in e-health are understood. The first refers to health science students, and the second refers to health professionals. The issue of possessing the skills with which to operate e-health technology is essential in spreading the use of e-health. As research demonstrates, "educating health care professionals with the necessary skill training in e-health care will improve service delivery" [44]. Findings also refer to the education process.

The second building block of e-health is the legal framework [41]. It is argued that "more specific e-health law would help clarify roles, rights and responsibilities of the various stakeholders" [45]. As a lack of trust is perceived to be one of the main obstacles to the implementation of e-health solutions, Geissbuhler states, "Trust amongst stakeholders can be strengthened through consensual formalization of rules into a specific law" [45]. Therefore, we can conclude that the more differentiated the purposes of legislation policy, the better it is for ehealth adoption.

The telehealth block covers five national programmes: teleradiology, teledermatology, telepathology, telepsychiatry, and remote patient monitoring. A study on telehealth adoption among US hospitals showed that the rate of hospital telehealth is associated with differences in state policy [1]. The most common aspect of research is on an organisational level, i.e., telehealth adoption in hospitals [46] or among individuals from specific groups, such as older people [47-49]. As telehealth is considered at an individual level (clinician to clinician, clinician to patient), it is also connected with the health professional workforce and - to some extend - with electronic health records [50]. Detailed studies have been conducted on the electronic health communication between physicians and patients [51]. The bottom-up approach, i.e., a patient's perspective, has also been considered in the study of factors influencing the adoption of e-health in developing countries [52].

The fourth block is electronic health records (EHRs). It is divided into four parts. The first constitutes the national EHR system and legislation governing its use. The other parts are health facilities with EHRs, the existence of the domain electronic system (e.g., laboratory, pathology), and ICT-assisted functions, such as electronic billing and supply. EHRs cover different information systems that have various scopes supporting single functions, activities for particular organisations, more interoperability of the solutions used at the national level, etc. [53]. Research into the community level of EHR use has proved that data collection and presentation in this area should be standardised [54].

According to a recent study, the use of e-learning in health education (fifth building block) is still not fully recognised and requires a model for evaluating learning in e-health [55]. Nevertheless, a systematic review of the effectiveness of e-learning showed that this form of 
education was evaluated slightly higher than traditional education means but with some limitations [56].

M-health programmes (sixth building block) are divided into three groups: accessing/providing health services (6), accessing/providing health information (5), and collecting health information (3).

An analysis of the previous WHO survey showed that $\mathrm{m}$-health is "characterised by small-scale pilot projects that address single issues in information sharing and access" [10]. The narrative literature review suggests that m-health projects lack a complex design targeted at point solutions [57].

Social media (seventh building block) cover three issues. The first one concerns policy/strategy regulating the use of social media in the health domain by governmental organisations. The next deals with healthcare organisations using social media. The last one refers to the use of social media by individuals and communities. Literature about using social media in the e-health context suggests that the motive behind such use is that of selfcare and self-management [58] or patient empowerment [59]. It also noticed that social media are reshaping the way in which doctors and patients interact [60].

The eighth and last building block is big data. In the WHO survey, this issue is covered by two related topics dealing with governing the use of big data in the health sector and by private companies. Big data are perceived to be one of the most important issues that must be considered in ehealth solutions [61]. Studies show a broad spectrum of potential utilisation, yet there are still some serious challenges to overcome in the area of big data analytics [62].

Among the most recent changes in the e-health systems implemented in Estonia and Lithuania is a special portal dedicated to patients that allows them to monitor their medical data and appoint representatives and health information systems (with electronic health records), allowing doctors to obtain quick access to a patient's complete health information. As natural consequences of these two, e-prescription was initialised, accompanied by digital registration and electronic medical certificates.

In the Czech Republic, legal regulations on patients' medical records are being formulated, and only eprescription is operational but only on a limited scale [63]. Ordering prescriptions by telephone (or to be exact: by emailing a primary physician) is considered as (relatively) simple procedure, very appreciated by patients. Ordering prescriptions by email is well developed only in Estonia. Such a system is in its infancy in Poland in 2019.

In Bulgaria, measures such as electronic consultation requests, e-prescriptions, and electronic health registers have not yet been achieved, although the "Strategy for the Implementation of e-Healthcare in Bulgaria" has been adopted [64]. In Hungary, the implementation of the e-health system is progressing. Primary care physicians operating in the public sector as well as pharmacies had to register by 1 November 2017 in the national electronic health records system, while private primary health practices were supposed to do so by 1 November 2018 [63].

In Poland, e-health solutions have been a policy priority for over a decade, but progress has been slow and patient health books are still kept in paper form. Eprescriptions and e-referrals are still on the initial steps of development since full implementation of these two programmes has been postponed a number of times (currently until 2020-21). Furthermore, the implementation of e-solutions is more advanced in the hospital sector, especially in the largest hospitals, than in ambulatory care. E-doctor sick-leave certificates have been launched recently. As a result, the functionality of ehealth in Poland has been questioned [65].

To summarise: Comparative studies on e-health in CEE countries are rare. The scope of e-health-related conditions is diversified in CEE countries, both within particular areas and among them. There is no alternative for digital healthcare tools since an increasing number of consumers are using them, and interest in greater digital engagement continues to rise [64].

Based on the narrative literature review and the available data on e-health, we have distinguished and described the most important areas and factors in e-health implementation. Current studies indicate a diversified picture of e-health conditions in CEE countries. The purpose of our analysis was to investigate how these factors influenced (and to what extent) the implementation and use of e-health solutions within these countries.

Referring to the measurement of outcomes, and based on these indicators, the countries with high use of ehealth services are as follows: Estonia (49 and 30\%, respectively), Croatia (33 and 26\%), Latvia (23 and 23\%), and Slovenia (20 and 15\%). Ordering prescriptions by telephone (or by emailing a primary physician) is considered a relatively simple procedure that patients very much appreciate. This is why it was used in the research.

We report the results of our QCA in more tables below. First, the positions of the analysed CEE countries are presented in Table 1, the countries we consider to be characterised by high use of e-health services in bold. Only Estonia was ranked above the EU27+3 average. Three other countries showed an average better than the EU27+3 average with respect to Availability \& Use Composite Indicators. Six out of the 10 analysed CEE countries scored below the EU27+3 average with respect to both composite indicators. This shows that in the researched hospitals, the effective use of e-health tools and procedures is far below expectations (and, possibly, needs).

Similar research into acute hospitals [66] to a great extent strengthens the above-presented assessments. The 
Table 1 E-health Composite Indicators for Hospitals in Selected Countries Compared to the EU27+3 Average (2012)

\begin{tabular}{lll}
\hline Country & Deployment Composite Indicators & Availability \& Use Composite Indicators \\
\hline Estonia & + & + \\
Croatia & - & + \\
Czech Republic & - & + \\
Hungary & - & + \\
Bulgaria & - & - \\
Latvia & - & - \\
Lithuania & - & - \\
Poland & - & - \\
Romania & - & - \\
Slovenia & - & - \\
\hline
\end{tabular}

Key: - means "below EU $27+3$ average"; + means "above EU27+3 average"

Source: own compilation based on [66]

selected findings from this study show that the use of ehealth in CEE countries requires improvement.

Table 2 shows that the use of EMRs, EHRs and EPRs in four of the analysed countries (Croatia, Czech Republic, Estonia, and Hungary) is above the EU27+3 average. Furthermore, four of the countries (Croatia, Czech Republic, Estonia, and Latvia) showed better results than the EU27+3 average with respect to the exchange of clinical care information about patients. Nevertheless, in general, the positions of the national e-health profiles of the analysed countries within the EU27+3 are weak. This correlates with our findings.

The results of the 2015 WHO GOE survey about e-health in CEE countries [32] present a chronology of the introduction of e-health policy in the CEE countries, as well as a juxtaposition of the introduction times, particularly of e-health national policies (Table 3). The first countries to introduce e-health policies were Estonia and Latvia, followed by Lithuania, Poland, Croatia, and Bulgaria. Table 4 contains the main observations derived from a comparison of the results for the CEE countries.

Table 5 lists the final set of conditions for the implementation of e-health that we used for our analysis. All these conditions are already mentioned in the eHealth survey by the WHO Global Observatory [31, 32].

Referring to the QCA analysis, we conducted conventional crisp set analysis, where set membership is binary (Table 6). Our data also indicate that there are three combinations of conditions leading to the effective implementation of e-health services (Table 7). The most complex situation that we observe is found in combination 3. Nine conditions led to the high use of e-health services in Estonia. The other two combinations possess fewer conditions: only TRAINING and MHEALTH are found in both.

Combination 1 is found in Latvia and Slovenia, while combination 2 is found in Hungary. Then, we searched for parsimonious solutions, which refer to any causal combination that uses at least some of the causal conditions specified in the complex solution as a valid solution of the truth table, as long as it contains all of the causal conditions specified in the parsimonious solution. Nine such solutions appeared. In Estonia and Hungary, national e-health information system (HIS) policy and the established telehealth programme (TELEPROG) are crucial conditions for achieving the outcome. In Latvia and Slovenia, eight parsimonious combinations emerged. In two of them, the key conditions are related to both established $\mathrm{m}$-health programmes and pre- and inservice training.

In the next four combinations, the condition related to legally defined medical jurisdiction, liability or reimbursement of e-health services (MED_JURIS) was found. This condition is also present in the next combination, along with established $\mathrm{m}$-health programmes (although a national information system or policy is not reported). In the last parsimonious combination, established $\mathrm{m}$ health programmes appear, but the sharing of digital data between health professionals in other health services in the same country via EHR is not regulated.

We also wanted to know which conditions are necessary for the successful outcome to occur. For this purpose, we examined the necessary conditions via the consistency and coverage scores for individual conditions (Table 8). Consistency indicates the degree to which the causal condition is a superset of the outcome, and coverage indicates the empirical relevance of a consistent superset. There is one condition that is always associated with a successful outcome: pre- and in-service training. This finding supports a previous study on implementing e-health initiatives, where such initiatives would succeed if, among others, they fit well with the skill sets of the existing staff [34]. The next three necessary conditions with a consistency of 0.75 are as follows: POLICY, IND_ACC, 
Table 2 Type of Electronic Medical Records (EMRs) / Electronic Health Records (EHRs) / Electronic Patient Records (EPRs) and Exchange of Clinical Care Information Used by the Hospitals in Selected Countries

\begin{tabular}{|c|c|c|c|c|c|c|}
\hline Country & $\begin{array}{l}\text { Hospital-wide EMR/ } \\
\text { EHR/EPR shared by all } \\
\text { clinical services (\%) }\end{array}$ & $\begin{array}{l}\text { Multiple loc/dept. } \\
\text { EMR/EHR/EPR, which } \\
\text { share information (\%) }\end{array}$ & $\begin{array}{l}\text { Multiple loc/dept. } \\
\text { EMR/EHR/EPR, not } \\
\text { sharing information } \\
(\%)\end{array}$ & $\begin{array}{l}\text { No. EMR/EHR/EPR } \\
\text { systems used in } \\
\text { the hospital (\%) }\end{array}$ & $\begin{array}{l}\text { No. exchanges of } \\
\text { clinical care } \\
\text { information about } \\
\text { patients (\%) }\end{array}$ & $\begin{array}{l}\text { Position of the } \\
\text { national e-health } \\
\text { profile within } \\
\text { EU27+3 }\end{array}$ \\
\hline $\begin{array}{l}\text { EU27+3 } \\
\text { average }\end{array}$ & 57 & 21 & 6 & 16 & 43 & $\mathrm{n} / \mathrm{a}$ \\
\hline $\begin{array}{l}\text { Czech } \\
\text { Republic }\end{array}$ & 82 & 3 & 3 & 12 & 35 & exceeds \\
\hline Estonia & 100 & 0 & 0 & 0 & 8 & surpasses \\
\hline Croatia & 82 & 9 & 9 & 0 & 27 & close \\
\hline Hungary & 86 & 12 & 2 & 0 & 60 & close \\
\hline Latvia & 75 & 12 & 12 & 1 & 26 & $\begin{array}{l}\text { uneven } \\
\text { development }\end{array}$ \\
\hline Lithuania & 23 & 30 & 10 & 37 & 75 & behind \\
\hline Bulgaria & 39 & 25 & 18 & 18 & 52 & underperforming \\
\hline Poland & 50 & 7 & 7 & 36 & 71 & behind \\
\hline Slovenia & 33 & 17 & 17 & 33 & 83 & behind \\
\hline Romania & 61 & 17 & 4 & 18 & 71 & significantly behind \\
\hline
\end{tabular}

Source: own compilation based on [66]

and MHEALTH. They can be explained as the possibility of individual access to their data within $\mathrm{m}$-health programmes guaranteed by national e-health policy.

After defining the set of conditions leading to effective e-health implementation, we wanted to investigate which conditions (or lack of conditions) contribute to a lack of high use of e-health services. The analysis showed that none of the countries characterised by low use of ehealth services have the same combination of conditions (Table 9).

We also generated four parsimonious solutions. In the first solution, low e-health service use is connected with a lack of established TELEPROG and MHEALTH programmes. In the second, the lack of both established telehealth programmes and legally defined medical jurisdiction, liability or reimbursement of e-health services occur. The third is related to the lack of a national information system and legally defined medical jurisdiction, liability or reimbursement of e-health services. The last includes the cases in which the sharing of digital data between health professionals in other health services in the same country through the use of an HER is regulated, but a national information system is missing.

\section{Discussion}

As indicated above, the findings are inconclusive, although the analysed countries have the same heritage (post-socialist political systems with a centralised Semashko's model of healthcare [19]) and a rather homogenous cultural profile. Our analysis shows that

Table 3 The Introduction Years of E-health National Policies or Strategies in CEE Countries

\begin{tabular}{|c|c|c|c|c|c|}
\hline Country & E-health & Universal health coverage & Health information system & Telehealth & Number of policies/strategies \\
\hline Estonia & 2003 & 2008 & 2014 & & 3 \\
\hline Latvia & 2005 & 2014 & & & 2 \\
\hline Lithuania & 2010 & 2014 & & 2011 & 3 \\
\hline Poland & 2011 & 2004 & 2011 & & 1 \\
\hline Croatia & 2012 & 2012 & 2010 & 2010 & 4 \\
\hline Bulgaria & 2014 & 1999 & & & 2 \\
\hline Czech Republic & & 2013 & 2002 & & 2 \\
\hline Hungary & & 2014 & & & 1 \\
\hline Romania & & & & & - \\
\hline Slovenia & & & & & - \\
\hline Number of countries & 6 & 8 & 4 & 2 & \\
\hline
\end{tabular}

Source: own elaboration based on WHO's Atlas of e-health country profiles [32] 
Table 4 E-health in CEE Countries

\begin{tabular}{|c|c|}
\hline E-health dimension & Main conclusions \\
\hline 1. E-health strategy & $\begin{array}{l}\text { The most common e-health national policy or strategy in the CEE countries concerns universal health. Policy de- } \\
\text { voted to e-health can be observed in } 6 \text { of } 10 \text { CEE countries. E-health policies were established between } 2003 \text { and } \\
\text { 2014. Policy for telehealth is less popular (two cases). }\end{array}$ \\
\hline 2. E-health funding sources & In all of the 10 countries, public sources fund e-health. The next popular source is donor/non-public funding. \\
\hline 3. Training in e-health & $\begin{array}{l}\text { E-health capacity building exists in each of the countries investigated, with a slight dominance of pre-service } \\
\text { training. }\end{array}$ \\
\hline 4. Legal frameworks for e-health & $\begin{array}{l}\text { The most multipurpose e-health policies exist in Estonia (12), Lithuania (12), Latvia (11), next Slovenia (10), Hungary } \\
\text { (9), Romania (9), Bulgaria (8), and finally Poland (5), Croatia (4) and Czech Republic (4). }\end{array}$ \\
\hline 5. Telehealth & Only in three countries have telehealth programmes been established at a national level. \\
\hline $\begin{array}{l}\text { 6. Electronic health records } \\
\text { (EHRs) }\end{array}$ & $\begin{array}{l}\text { Countries that reported possessing a national EHR system also reported having adequate legislation regulating its } \\
\text { use. The system appears in three countries (Estonia, Lithuania, and Romania). }\end{array}$ \\
\hline $\begin{array}{l}\text { 7. mHealth programmes country } \\
\text { overview }\end{array}$ & $\begin{array}{l}\text { mHealth programmes were most intensively applied in Estonia and Lithuania (8 of 14), followed by Latvia (7/14) } \\
\text { and Hungary (4/14). }\end{array}$ \\
\hline 8 Social media & Usage not reported \\
\hline 9. Big data & Only in two countries is this issue considered: Lithuania and Slovenia. \\
\hline
\end{tabular}

Source: own elaboration based on WHO's Atlas of e-health country profiles [32]

Table 5 Conditions for the Implementation of E-health

\begin{tabular}{|c|c|c|c|c|}
\hline Category & Abbreviation & Conditions & Data treatment explanation & Codes \\
\hline \multirow{2}{*}{$\begin{array}{l}\text { National } \\
\text { policy or } \\
\text { strategy }\end{array}$} & POLICY & National e-health policy & Reported policy for particular country. & $\begin{array}{l}0 \text { - absent } \\
1 \text { - present }\end{array}$ \\
\hline & HIS & $\begin{array}{l}\text { National health information system (HIS) policy } \\
\text { or strategy }\end{array}$ & Reported policy for particular country. & $\begin{array}{l}0 \text { - absent } \\
1 \text { - present }\end{array}$ \\
\hline $\begin{array}{l}\text { Funding } \\
\text { sources }\end{array}$ & FUNDING & E-health funding sources & $\begin{array}{l}\text { Covers several sources: public funding; private or } \\
\text { commercial funding; donor/ not-public funding; } \\
\text { public-private partnership. }\end{array}$ & $\begin{array}{l}0 \text { - no or one } \\
\text { funding source } \\
\text { reported } \\
1 \text { - three } \\
\text { funding sources } \\
\text { reported }\end{array}$ \\
\hline $\begin{array}{l}\text { Capacity } \\
\text { building }\end{array}$ & TRAINING & E-health capacity building & $\begin{array}{l}\text { Includes: Health sciences students - Pre-service } \\
\text { training in e-health and health professionals - In- } \\
\text { service training in e-health. }\end{array}$ & $\begin{array}{l}0 \text { - no or only } \\
\text { pre-service or } \\
\text { only in-service } \\
\text { training } \\
1 \text { - both pre- } \\
\text { and in-service } \\
\text { training present }\end{array}$ \\
\hline \multirow[t]{3}{*}{$\begin{array}{l}\text { Legal } \\
\text { frameworks }\end{array}$} & MED_JURIS & $\begin{array}{l}\text { Policy of e-health legislation defines medical jur- } \\
\text { isdiction, liability or reimbursement of e-health } \\
\text { services }\end{array}$ & Reported purpose for given country. & $\begin{array}{l}0 \text { - absent } \\
1 \text { - present }\end{array}$ \\
\hline & DATASHARE & $\begin{array}{l}\text { Policy of e-health legislation governs the sharing } \\
\text { of digital data between health professionals in } \\
\text { other health services in the same country } \\
\text { through the use of an her }\end{array}$ & Reported purpose for given country. & $\begin{array}{l}0 \text { - absent } \\
1 \text { - present }\end{array}$ \\
\hline & IND_ACC & $\begin{array}{l}\text { Policy of e-health legislation allows individuals } \\
\text { electronic access to health-related data (when } \\
\text { held in EHRs) }\end{array}$ & Reported purpose for given country. & $\begin{array}{l}0 \text { - absent } \\
1 \text { - present }\end{array}$ \\
\hline \multirow[t]{3}{*}{$\begin{array}{l}\text { Programmes } \\
\text { at national } \\
\text { level }\end{array}$} & TELEPROG & Telehealth & $\begin{array}{l}\text { Includes five telehealth programmes: } \\
\text { teleradiology, teledermatology, telepathology, } \\
\text { telepsychiatry, and remote patient monitoring. } \\
\text { We included only established or pilot } \\
\text { programmes at the national level. }\end{array}$ & $\begin{array}{l}0 \text { - absent } \\
1 \text { - present }\end{array}$ \\
\hline & HER & Electronic Health Records (EHRs) & We included only the national EHR system & $\begin{array}{l}0 \text { - absent } \\
1 \text { - present }\end{array}$ \\
\hline & MHEALTH & mHealth programmes country overview & $\begin{array}{l}\text { We counted only those at the national level that } \\
\text { are in the pilot or established phase. }\end{array}$ & $\begin{array}{l}0 \text { - absent } \\
1 \text { - present }\end{array}$ \\
\hline
\end{tabular}




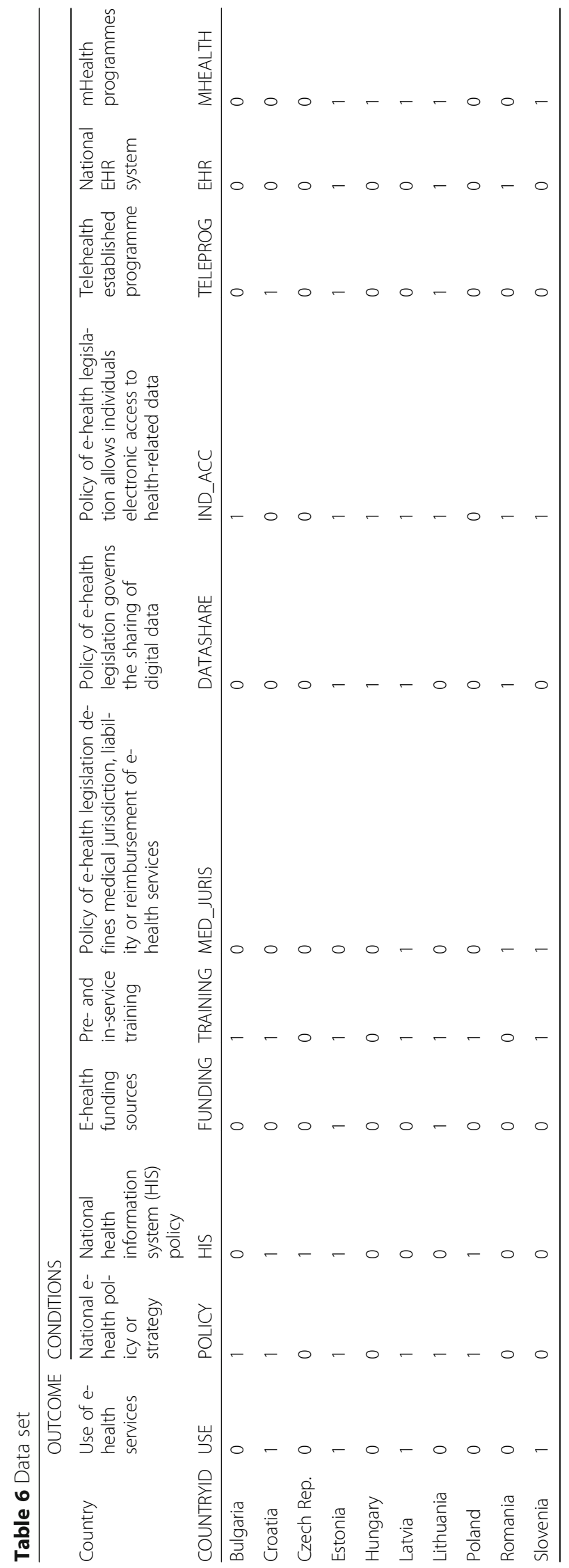


Table 7 Results of the analytical procedure

\begin{tabular}{llll}
\hline Condition & Combination 1 & Combination 2 & Combination 3 \\
\hline POLICY & $\times$ & $\bullet$ & $\bullet$ \\
HIS & $\circ$ & $\bullet$ & $\bullet$ \\
FUNDING & $\circ$ & $\circ$ & $\bullet$ \\
TRAINING & $\bullet$ & $\bullet$ & $\bullet$ \\
MED_JURIS & $\bullet$ & 0 & $\circ$ \\
DATASHARE & $\circ$ & $\circ$ & $\bullet$ \\
IND_ACC & $\bullet$ & $\circ$ & $\bullet$ \\
TELEPROG & $\circ$ & $\bullet$ & $\bullet$ \\
HER & $\circ$ & $\circ$ & $\bullet$ \\
MHEALTH & $\bullet$ & $\bullet$ & $\bullet$ \\
COUNTRYID & LV, SLO & HU & EST
\end{tabular}

Key: $\bullet$ - presence, $\circ-$ absence, $x$ - not included

there is no one way that leads to the successful or unsuccessful implementation of e-health. However, for both implementation outcomes, some factors are important (e.g., TRAINING in regard to success or MED_ JURIS, TELEPROG or HIS in regard to failure). In other words, boundary conditions for the successful implementation of e-health are MED_JURIS, TELEPROG and HIS, while TRAINING is a necessary condition.

Our findings correspond to the results of other studies. Sabes-Figuera \& Maghiros [66] researched hospitals in 27 EU countries (plus three others: Iceland, Norway and Croatia) between 2010 and 2012 using composite indicators grouped as e-health deployment and e-health availability and use. The indicator for e-health deployment was based on 45 variables grouped into four dimensions (infrastructure, applications, health information exchange, and security and privacy). The e-health availability and use indicator was based on information from a survey on the level of availability and use in each hospital of 39 different e-health functionalities pertaining to four categories (view/input information on EHR, clinical decision support on EHR, health information exchange, and telehealth) [33].

Table 8 Analysis of necessary conditions

\begin{tabular}{lll}
\hline Condition & Consistency & Coverage \\
\hline TRAINING & 1.00 & 0.57 \\
POLICY & 0.75 & 0.50 \\
IND_ACC & 0.75 & 0.43 \\
MHEALTH & 0.75 & 0.61 \\
HIS & 0.50 & 0.50 \\
MED_JURIS & 0.50 & 0.68 \\
TELEPROG & 0.50 & 0.68 \\
FUNDING & 0.25 & 0.50 \\
DATASHARE & 0.25 & 0.25 \\
her & 0.25 & 0.33 \\
\hline
\end{tabular}

A separate but important issue is the level of e-health skills, first among patients (both current and prospective). Vicente \& Madden [67] prove that e-health skills can be tied not only to level of education (as shown through WHO data) but also to age and health status. Their findings show that the most vulnerable groups comprise - along with the less educated - the sick and the elderly [67]. The lack of e-health skills among senior citizens is broadly recognised [51]. This fact gains value when keeping in mind that e-health strategies have enormous potential to support active ageing [68].

Our findings are consistent with the general mechanisms/rules for managing change in healthcare as indicated in the literature $[69,70]$ and with the conditions for more specific, medically-oriented changes introduced in healthcare organisations [71].

This study has certain limitations that can be classified as internal or external. The first relates to the character of the WHO data on e-health in the analysed CEE countries. Notwithstanding the value of the data, one may observe certain weaknesses. As we used secondary data from WHO survey, the empirical results reported in this study should be considered in the light of limitations related to experts' evaluation of given dimension of ehealth policy for analysed country. More rigorous analysis of the WHO data shows that some links on the WHO web page on national strategies on e-health [31] were either not present or not found and that the indicated acts and legal regulations were available exclusively in local languages. ${ }^{1}$ One should also point at the focus on macro level and programmes initiated and run by the government leaving various interesting regional and local initiatives and programmes apart. Such an unwilling bias does not mean that the analysis is valid only for countries having comparatively highly centralized health care systems. Everywhere in the world, highly decentralized and market-oriented national health care systems including, the government is responsible for nationwide health policy. There are not systemic barriers for the government to initiate, support and run initiatives and programmes aimed at e-health.

Another important issue is the slightly biased, positive manner in which national strategies of e-health development are presented. ${ }^{2}$ Separate but worth acknowledgement

\footnotetext{
${ }^{1}$ For example, the source for the Hungarian Information Society Strategy, Health and Social Services was removed (http://www.eski.hu/ eprogram/english/Mitsesz.pdf). The Lithuanian eHealth strategy is available only as Dél Lietuvos E. Sveikatos 2007-2015 Metu Plètros Strategijos Patvirtinimo (http://www3.lrs.lt/pls/inter3/oldsearch. getfmt? $\mathrm{C} 1=\mathrm{e} \& \mathrm{C} 2=306637$ ), and the Romanian strategy is available as Romania Strategia de e-Sănătate a Ministerului Sănătății (http://www. ms.gov.ro/documente/256_588_Anexa\%20strategie\%20e-sanatate.doc). ${ }^{2}$ Since there were national governments and/or ministries of health responsible for the preparation of such strategies, it is not surprising that they were presented in a positive and optimistic way.
} 
Table 9 Results of the analytical procedure

\begin{tabular}{|c|c|c|c|c|c|c|}
\hline Condition & Combination 1 & Combination 2 & Combination 3 & Combination 4 & Combination 5 & Combination 6 \\
\hline POLICY & $\circ$ & $\circ$ & $\circ$ & $\bullet$ & $\bullet$ & $\bullet$ \\
\hline HIS & $\bullet$ & $\circ$ & $\circ$ & $\bullet$ & $\circ$ & $\circ$ \\
\hline FUNDING & $\circ$ & ○ & $\circ$ & $\circ$ & $\circ$ & $\bullet$ \\
\hline TRAINING & $\circ$ & $\circ$ & $\circ$ & $\bullet$ & $\bullet$ & $\bullet$ \\
\hline MED_JURIS & $\circ$ & $\bullet$ & $\circ$ & $\circ$ & $\circ$ & $\circ$ \\
\hline DATASHARE & $\circ$ & $\bullet$ & $\bullet$ & $\circ$ & $\circ$ & $\bullet$ \\
\hline IND_ACC & $\circ$ & $\bullet$ & $\bullet$ & $\circ$ & $\bullet$ & $\bullet$ \\
\hline TELEPROG & $\circ$ & $\circ$ & $\circ$ & $\circ$ & $\circ$ & $\bullet$ \\
\hline HER & $\circ$ & $\circ$ & $\circ$ & $\circ$ & $\circ$ & $\bullet$ \\
\hline MHEALTH & $\circ$ & $\circ$ & $\bullet$ & $\circ$ & $\circ$ & $\bullet$ \\
\hline COUNTRYID & $C Z$ & $\mathrm{RO}$ & $\mathrm{HA}$ & $\mathrm{PL}$ & BG & LT \\
\hline
\end{tabular}

Key: • means "condition present"; ○ means "condition absent"

is the fact that the WHO data do not cover the most recent developments (i.e., 2014-2018) of e-health in the respective countries.

Last but not least is the size (only 10 countries) and composition (post-socialist, CEE countries) of the sample thus one may indicate that the findings have limited value.

Moreover, a number of challenges are associated with the QCA method. The data we used and their weaknesses directly affect the analyses. They determined the outcome and conditions. From this perspective, identifying the conditions was a great challenge. The selection process had to be restrictive, as QCA does not allow the inclusion of a large number of conditions. Another challenge emerged concerning the way in which we assessed the outcomes. As noted, we defined the outcome as the successful implementation of e-health services. However, other studies on healthcare in selected Central Eastern European countries used the overall satisfaction of healthcare users [72]. The implementation of the ehealth strategy is a very complex process. Our analyses are related only to the paths of e-health implementation in CEE countries thus consequently the findings and conclusions cannot be directly applied to other countries or sub-continents characterized by significant technological, economic, social, demographic differences. Therefore, an interesting subject of study would be the comparison of the implementation paths in CEE and other countries. The external limitations of this study are related the absence of a broader context of ehealth development, including the development of ICT infrastructure and ICT literacy. Here, the functional side of e-health in the respective countries should be rigorously analysed with a special emphasis on medical professionals' and patients' skills in e-health since the lack of ICT skills negatively influences regional e-health implementation [65].

\section{Conclusions}

The results of the study provide various conclusions and implications. First, we observe that analysed CEE countries are slowly progressing with e-health implementation, with Estonia being the undisputed leader. The selected indicators of EMRs, EHRs and EPRs and an exchange of clinical care information in hospitals show that the analysed countries are trying to catch up with the EU27+3 average; in general, however, the positions of the national e-health systems in the analysed countries within the EU27+3 remain weak. The most advanced countries in e-health service use are Latvia, Slovenia, Hungary, and Estonia. All of them (except for Slovenia) are pioneers in introducing e-health policy in the CEE countries.

Slovenia is an atypical case according to our analysis. This country reported relatively high use of e-health services and was characterised by a lower number of conditions facilitating the use of e-health, which is consistent with the findings of Sabes-Figuera \& Maghiros [66] and our analysis. An additional query on e-health development in Slovenia shows that an e-health project was launched in 2005 but that it is still not fully operational (expected in 2020) due to various deficiencies [73]. The QCA analysis used for e-health development in the analysed CEE countries showed that to achieve success in ehealth implementation, legal medical jurisdiction, teleprogrammes and EHRs must be in place (supplemented by adequate training). Moreover, the paper indicates a considerable research gap with respect to e-health implementation in the analysed countries.

Referring to managerial and policy implications, the paper shows that the use of e-health services depends on enabling technology-supporting relations between patients and well-skilled clinicians. This study fosters observation regarding the need "for hospitals and decision makers to clearly identify and act on the drivers of 
successful implementations [of e-health solutions]" [74]. Moreover, it reduces uncertainty about the factors having an influence, as many barriers are observed [34].

For policymakers, it is clear that governments should support the development of e-health programmes via ehealth legislation with special attention to medical jurisdiction, liability or reimbursement of e-health services. This study observes several obstacles to introducing $\mathrm{m}$ health policy, such as data security, licensure, and patient confidentiality and privacy [75]. Another recommendation for managers and policy-makers is the development of training programmes for health science students and health professionals. This is the condition sine qua non for spreading the use of e-health services in countries where these solutions are not popular among society.

\section{Abbreviations}

CEE: Central Eastern European; EHRs: Electronic Health Records; EMRs: Electronic Medical Records; EPRs: Electronic Patient Records; EU: European Union; EU27+3: European Union 27 countries plus three others: Iceland, Norway and Croatia; HIS: Health information system; HIT: Health IT; ICT: Information and Communication Technology; QCA: Qualitative Comparative Analysis; WHO GOE: WHO Global Observatory for eHealth

\section{Acknowledgements}

We would like to thank the reviewers of this journal for their insightful and constructive comments towards improving our manuscript.

\section{Author biographies}

MĆ is a Professor of Business Studies and Public Management and Head of Department for Management of Public Organisations at the Cracow University of Economics in Poland. He researches, writes, and lectures on organisation theory, business research methodology, and public management. He is a habilitated doctor of Economics within the discipline of management science, and holds PhD in Economics science within the field of Management Science, both obtained in Cracow University of Economics in Poland.

$\mathrm{JK}$ is an associate professor at Department for Management of Public Organisations in Cracow University of Economics in Poland. He holds Ph.D. in political science (1988), Ph.D. in economics (1995) and habilitation in economics (2009). He is an author and co-author of several books and over one hundred articles published in Polish, English, German, Ukrainian and Serbian. His research covers such wide scope of areas as entrepreneurship and small and medium-sized firms, private sector development in transformed economies (with a special emphasis on health care systems), and management in health care.

$\mathrm{KP}$ is a research assistant in the Department for Management of Public Organisations at the Cracow University of Economics. She graduated from sociological and public relations studies at Jagiellonian University. She lectures on public relations, economy and public administration and information management. Her research interests include methodology of marketing and social research, place branding and analysis of public policies. FS is an associate professor in management at University Parthenope, Naples, Italy. He received the Ph.D. degree in network economics and knowledge management from the Ca' Foscari University of Venice (Italy) in 2006. He is also an Affiliated Professor in innovation management at Paris School of Business and Visiting Professor at IESEG Business School (France). In April 2017 he has been habilitated as Full Professor in management by MIUR (Italian Ministry of Education and Research). Currently, his main research areas are technology management, strategic innovation, communities of practice, and healthcare management and innovation.

\section{Authors' contributions}

FS contributed to the conception of the study, reflective discussions on the analysis and prepared the technical proposal. MC and KP contributed to the conception and design of the study, and the data collection, analysis with support from JK and FS. JK contributed to the interpretation of the data and drawing conclusions. All authors contributed to interpretation of findings and preparing, reading, revising, and approving the manuscript. All authors read and approved the final manuscript.

\section{Funding}

Funding for this research was provided by the University of Naples Parthenope for the language editing and proofreading. Funding for the article-processing charge and proof reading of revised version of the paper is provided by the Cracow University of Economics.

\section{Availability of data and materials}

The datasets used and analysed during the current study are available from the corresponding author on reasonable request.

\section{Ethics approval and consent to participate}

Not applicable.

\section{Consent for publication}

Not applicable.

\section{Competing interests}

The authors declare that they have no competing interests.

\section{Author details}

${ }^{1}$ Department of Management of Public Organisations, Cracow University of Economics, ul. Rakowicka 27, 31-510 Cracow, Poland. ${ }^{2}$ Department of Management Studies \& Quantitative Methods, University of Naples Parthenope, Via Generale Parisi 13, 80132 Naples, Italy. ${ }^{3}$ Department of Strategy and Management, Paris School of Business, 59 Rue Nationale, 75013 Paris, France.

Received: 23 April 2019 Accepted: 25 February 2020

Published online: 04 March 2020

\section{References}

1. Adler-Milstein J, Kvedar J, Bates DW. Telehealth among US hospitals: several factors, including state reimbursement and licensure policies, influence adoption. Health Aff (Millwood). 2014;33:207-15.

2. Matt C, Hess T, Benlian A. Digital transformation strategies. Bus Inf Syst Eng. 2015;57:339-43.

3. Agarwal R, Gao G, DesRoches C, Jha AK. Research commentary —-the digital transformation of healthcare: current status and the road ahead. Inf Syst Res. 2010;21:796-809.

4. Topol EJ. The creative destruction of medicine: how the digital revolution will create better health care. New York: Basic Books; 2013.

5. Coile RC. The digital transformation of health care. Physician Exec. 2000;26:8-15.

6. Bashshur R, Shannon G, Krupinski E, Grigsby J. The taxonomy of telemedicine. Telemed E-Health. 2011;17:484-94.

7. Eysenbach G. What is e-health? J Med Internet Res. 2001;3:e20.

8. Scott R, Mars M. Here We Go Again - "Digital Health.". J Int Soc Telemed EHealth. 2019;7. https://doi.org/10.29086/JISfTeH.7.e1.

9. Suzanne Suggs L, Rangelov N, Schmeil A, Occa A, Bardus M, Radchuk O, et al. e-Health Services. In: Ang PH, Mansell R, editors. The International Encyclopedia of Digital Communication and Society. Hoboken: Wiley; 2014. p. 1-9. https://doi.org/10.1002/9781118767771.wbiedcs080.

10. WHO Global Observatory for eHealth. MHealth: new horizons for health through mobile technologies. Geneva: World Health Organization; 2011. http:// www.who.int/goe/publications/goe_mhealth_web.pdf. Accessed 4 Aug 2018.

11. Nundy S, Lu C-YE, Hogan P, Mishra A, Peek ME. Using patient-generated health data from Mobile Technologies for Diabetes Self-Management Support: provider perspectives from an Academic Medical Center. J Diabetes Sci Technol. 2014;8:74-82.

12. Haddad SM, Souza RT, Cecatti JG. Mobile technology in health (mHealth) and antenatal care-searching for apps and available solutions: a systematic review. Int J Med Inf. 2019;127:1-8. 
13. Hsu J, Huang J, Kinsman J, Fireman B, Miller R, Selby J, et al. Use of e-health services between 1999 and 2002: a growing digital divide. J Am Med Inform Assoc. 2005;12:164-71.

14. Banerjee $S$, Hemphill T, Longstreet P. Wearable devices and healthcare: Data sharing and privacy. Inf Soc. 2018;34:49-57.

15. WHO Global Observatory for eHealth. Global diffusion of eHealth: making universal health coverage achievable: report of the third global survey on eHealth. 2016

16. Pavlínek P. Alternative theoretical approaches to post-communist transformations in central and Eastern Europe. Acta Slavica laponica. 2003; 2003:85-108.

17. Petsinis V. Twenty years after 1989: moving on from transitology. Contemp Polit. 2010;16:301-19.

18. Windak $A$, van Hasselt P. Primary care and general practice in Europe: central and east. In: Jones R, Britten N, Culpepper L, Grass D, Grol R, Mant D, et al., editors. Oxford Textbook of Primary Medical Care. New York: Oxford University Press; 2005. p. 70-3.

19. Sheiman I, Shishkin S, Shevsky V. The evolving Semashko model of primary health care: the case of the Russian Federation. Risk Manag Healthc Policy. 2018;11:209.

20. Grant MJ, Booth A. A typology of reviews: an analysis of 14 review types and associated methodologies: a typology of reviews, Maria J. Grant \& Andrew Booth. Health Inf Libr J. 2009;26:91-108.

21. Sætren H, Hupe PL. Policy implementation in an age of governance. In: Ongaro E, Van Thiel S, editors. The Palgrave handbook of public administration and Management in Europe. London: Palgrave Macmillan UK 2018. p. 553-75. https://doi.org/10.1057/978-1-137-55269-3_29.

22. Ragin CC. The comparative method. Moving beyond qualitative and quantitative strategies. Berkeley-Los Angeles: University of California Press; 1987.

23. Greckhamer T, Mossholder KW. Qualitative Comparative Analysis and Strategic Management Research: Current State and Future Prospects. In: Bergh DD, Ketchen, editors. Building Methodological Bridges. Bingley: Emerald Group Publishing Limited. p. 259-88.

24. Goicolea I, Christianson M, Hurtig A-K, Marchal B, San Sebastian M, Wiklund M. Searching for best practices of youth friendly services - a study protocol using qualitative comparative analysis in Sweden. BMC Health Serv Res. 2016;16. https://doi.org/10.1186/s12913-016-1570-8.

25. Rahm AK, Cragun D, Hunter JE, Epstein MM, Lowery J, Lu CY, et al. Implementing universal lynch syndrome screening (IMPULSS): protocol for a multi-site study to identify strategies to implement, adapt, and sustain genomic medicine programs in different organizational contexts. BMC Health Serv Res. 2018;18. https://doi.org/10.1186/s12913-018-3636-2.

26. Sheehy TJ, Thygeson NM. Physician organization care management capabilities associated with effective inpatient utilization management: a fuzzy set qualitative comparative analysis. BMC Health Serv Res. 2014;14. https://doi.org/10.1186/s12913-014-0582-5

27. Mair FS, May C, O'Donnell C, Finch T, Sullivan F, Murray E. Factors that promote or inhibit the implementation of e-health systems: an explanatory systematic review. Bull World Health Organ. 2012;90:357-64.

28. Fragidis $L L$, Chatzoglou PD. Development of Nationwide electronic health record (NEHR): an international survey. Health Policy Technol. 2017;6:124-33.

29. Ragin CC, Davey S. Fuzzy-set/qualitative comparative analysis 3.0. Irvine: Department of Sociology, University of California; 2016.

30. EUROFUND. European Qualify of Life Survey 2016. 2018. https://www. eurofound.europa.eu/surveys/european-quality-of-life-surveys/europeanquality-of-life-survey-2016. Accessed 3 Aug 2018.

31. WHO. Global Observatory for eHealth. 2018. http://www.who.int/goe/data/ en/. Accessed 3 Aug 2018.

32. WHO Global Observatory for eHealth, editor. Atlas of eHealth country profiles: the use of eHealth in support of universal health coverage: based on the findings of the third global survey on eHealth, 2015. Geneva: World Health Organization; 2016.

33. Hage E, Roo JP, van Offenbeek MA, Boonstra A. Implementation factors and their effect on e-health service adoption in rural communities: a systematic literature review. BMC Health Serv Res. 2013;13. https://doi.org/10.1186/ 1472-6963-13-19.

34. Murray E, Burns J, May C, Finch T, O'Donnell C, Wallace $P$, et al. Why is it difficult to implement e-health initiatives? A qualitative study. Implement Sci. 2011;6. https://doi.org/10.1186/1748-5908-6-6.

35. Mars M, Scott RE. Global E-health policy: a work in Progress. Health Aff (Millwood). 2010;29:237-43.
36. EC. eHealth Action Plan 2012-2020 - Innovative healthcare for the 21st century 2012. http://ec.europa.eu/newsroom/dae/document.cfm?doc_id=4188.

37. Greenhalgh T, Robert G, Macfarlane F, Bate P, Kyriakidou O. Diffusion of innovations in service organizations: systematic review and recommendations. Milbank Q. 2004;82:581-629.

38. Damschroder LJ, Aron DC, Keith RE, Kirsh SR, Alexander JA, Lowery JC. Fostering implementation of health services research findings into practice: a consolidated framework for advancing implementation science. Implement Sci. 2009;4. https://doi.org/10.1186/1748-5908-4-50.

39. Dobrev A, Jones T, Stroetmann VN, Stroetmann KA, Artmann J, Kersting A, et al. Sources of financing and policy recommendations to Member States and the European Commission on boosting eHealth investment. Final report of the Financing eHealth study. empirica; 2008.

40. Stroetmann KA, Artmann J, Stroetmann V. Developing national eHealth infrastructures--results and lessons from Europe. AMIA Annu Symp Proc AMIA Symp. 2011;2011:1347-54.

41. Khoja S, Durrani H, Nayani P, Fahim A. Scope of policy issues in eHealth: results from a structured literature review. J Med Internet Res. 2012;14:e34.

42. Klein GO, Kajbjer K. eHealth Tools for Patients and Professionals in a Multicultural World. Stud Health Technol Inform. 2009;150:297-301.

43. Ngo-Metzger Q, Massagli MP, Clarridge BR, Manocchia M, Davis RB, lezzoni $\mathrm{LI}$, et al. Linguistic and cultural barriers to care: perspectives of chinese and vietnamese immigrants. J Gen Intern Med. 2003;18:44-52.

44. Barakat A, Woolrych RD, Sixsmith A, Kearns WD, Kort HS. eHealth Technology Competencies for Health Professionals Working in Home Care to Support Older Adults to Age in Place: Outcomes of a Two-Day Collaborative Workshop. Med 20. 2013;2:e10.

45. Geissbuhler A. Lessons learned implementing a regional health information exchange in Geneva as a pilot for the Swiss national eHealth strategy. Int J Med Inf. 2013;82:e118-24.

46. Gagnon M, Lamothe L, Fortin J, Cloutier A, Godin G, Gagné C, et al. Telehealth adoption in hospitals: an organisational perspective. J Health Organ Manag. 2005;19:32-56.

47. Kim E, Gellis ZD, Bradway C, Kenaley B. Key determinants to using telehealth technology to serve medically ill and depressed homebound older adults. J Gerontol Soc Work. 2018;62:1-24.

48. Charness NH, Boot WR, Evans J, Best R, Taha J, Sharit J, et al. Constraints on telehealth adoption and use by older adults. Innov Aging. 2017;1(suppl_1):1026.

49. Dang S, Ruiz DI, Klepac L, Morse S, Becker P, Levy CR, et al. Key characteristics for successful adoption and implementation of home Telehealth Technology in Veterans Affairs Home-Based Primary Care: an exploratory study. Telemed EHealth. 2018. https://doi.org/10.1089/tmj.2018.0009.

50. Tuckson RV, Edmunds M, Hodgkins ML. Telehealth. N Engl J Med. 2017;377:1585-92

51. Razmak J, Bélanger $\mathrm{CH}$. Connecting technology and human behaviours towards e-health adoption. Int J Inf Syst Change Manag. 2017;9:169.

52. Hoque MR, Bao Y, Sorwar G. Investigating factors influencing the adoption of e-health in developing countries: a patient's perspective. Inform Health Soc Care. 2017:42:1-17.

53. Hayrinen K, Saranto K, Nykanen P. Definition, structure, content, use and impacts of electronic health records: a review of the research literature. Int $J$ Med Inf. 2008;77:291-304.

54. Gold R, Cottrell E, Bunce A, Middendorf M, Hollombe C, Cowburn S, et al. Developing electronic health record (EHR) strategies related to health center patients' social determinants of health. J Am Board Fam Med. 2017; 30:428-47.

55. Ruggeri K, Farrington C, Brayne C. A global model for effective use and evaluation of e-learning in health. Telemed E-Health. 2013;19:312-21.

56. George PP, Papachristou N, Belisario JM, Wang W, Wark PA, Cotic Z, et al. Online eLearning for undergraduates in health professions: a systematic review of the impact on knowledge, skills, attitudes and satisfaction. J Glob Health. 2014;4. https://doi.org/10.7189/jogh.04.010406.

57. Schweitzer J, Synowiec C. The economics of eHealth and mHealth. J Health Commun. 2012;17:73-81.

58. Antheunis ML, Tates K, Nieboer TE. Patients' and health professionals' use of social media in health care: motives, barriers and expectations. Patient Educ Couns. 2013;92:426-31.

59. Househ M, Borycki E, Kushniruk A. Empowering patients through social media: the benefits and challenges. Health Informatics J. 2014;20:50-8.

60. Hawn C. Take Two Aspirin And Tweet Me In The Morning: How Twitter, Facebook, And Other Social Media Are Reshaping Health Care. Health Aff (Millwood). 2009;28:361-8. 
61. Suciu G, Suciu V, Martian A, Craciunescu R, Vulpe A, Marcu I, et al. Big data, internet of things and cloud convergence - an architecture for secure E-health applications. J Med Syst. 2015;39. https://doi.org/10.1007/s10916-015-0327-y.

62. Belle A, Thiagarajan R, Soroushmehr SMR, Navidi F, Beard DA, Najarian K. Big data analytics in healthcare. Biomed Res Int. 2015;2015:1-16.

63. BNT. eHealth - implementation in CEE and protecting "sensitive" patient data |. bnt attorneys in CEE. 2018. https://www.bnt.eu/en/news/legalnews/2586-ehealth-implementation-in-cee-and-protecting-sensitive-patientdata. Accessed 1 Oct 2018.

64. INTOSAI. Bulgaria NAO Launches E-Health Analysis. International Journal of Government Auditing. 2017. http://intosaijournal.org/bulgaria-nao-launchesehealth-analysis/. Accessed 3 Oct 2018.

65. Kulisiewicz T. Systemy e-zdrowia - architektury informacyjne a oczekiwania społeczne [= E-health systems - information architectures vs. social expectations]. Rocz Kol Anal Ekon. 2015;38:399-409.

66. PriceWaterhouseCoopers. European Hospital Sunvey: Benchmarking Deployment of eHealth Services (2012-2013). Final Report. Luxembourg: Publ. Off. of the Europ. Union; 2014. https:/doi.org/10.2791/56790. Accessed 21 Aug 2018.

67. Vicente MR, Madden G. Assessing eHealth skills across Europeans. Health Policy Technol. 2017;6:161-8.

68. Robbins TD, Lim Choi Keung SN, Arvanitis TN. E-health for active ageing; a systematic review. Maturitas. 2018:114:34-40.

69. Al-Abri R. Managing change in healthcare. Oman Med J. 2007;22:9-10.

70. Antwi M, Kale M. Change Management in Healthcare. Literature review. Kingston: The Monieson Centre For Business Research in Healthcare, Queen's School of Business; 2014. https://smith.queensu.ca/centres/monieson/ knowledge_articles/files/Change\%20Management\%20in\%20Healthcare\%20-\%2 OLit\%20Review\%20-\%20AP\%20FINAL.pdf. Accessed 26 Sep 2018.

71. Kaluzny AD, O'Brien DM. Managing disruptive change in healthcare: lessons from a public-private partnership to advance Cancer care and research. New York: Oxford University Press; 2015.

72. Stepurko T, Pavlova M, Groot W. Overall satisfaction of health care users with the quality of and access to health care services: a cross-sectional study in six central and eastern European countries. BMC Health Serv Res. 2016;16. https://doi.org/10.1186/s12913-016-1585-1.

73. Stanimirović D. Development of eHealth in Slovenia - critical issues and future directions. Int Public Adm Rev. 2014:12:9-38.

74. Eden R, Burton-Jones A, Scott I, Staib A, Sullivan C. Effects of eHealth on hospital practice: synthesis of the current literature. Aust Health Rev. 2018. https://doi.org/10.1071/AH17255.

75. Malvey DM, Slovensky DJ. Global mHealth policy arena: status check and future directions. mHealth. 2017;3:41.

\section{Publisher's Note}

Springer Nature remains neutral with regard to jurisdictional claims in published maps and institutional affiliations.

Ready to submit your research? Choose BMC and benefit from:

- fast, convenient online submission

- thorough peer review by experienced researchers in your field

- rapid publication on acceptance

- support for research data, including large and complex data types

- gold Open Access which fosters wider collaboration and increased citations

- maximum visibility for your research: over $100 \mathrm{M}$ website views per year

At $\mathrm{BMC}$, research is always in progress.

Learn more biomedcentral.com/submissions 